\title{
FILM REVIEW
}

Joel Karekezi, director. The Mercy of the Jungle. 2018. 91 minutes. French and Kinyarwanda (with English Subtitles). Belgium/France. Neon Rouge Production. No price reported.

The eastern borderlands of the Democratic Republic of the Congo have long been the site of regional politics and conflict, and yet they have rarely been depicted on screen. In The Mercy of the Jungle, Rwandan filmmaker Joel Karekezi uses this evocative backdrop to deliver a complex, nuanced, and at times seductively entertaining follow-up to his first feature, Imbabazi: the Pardon (2013). In Imbabazi, Karekezi tackled the intensely personal issues of forgiveness and reconciliation after the 1994 genocide in Rwanda. With his second feature, Karekezi picks up temporally where he left off, focusing now on the larger geopolitical repercussions of the genocide, following the stream of people westward into the DRC and the violence that accompanied them. Inspired by the experiences of his Congolese cousin, Karekezi interrogates the meaning and meaninglessness of war, using the ecology of the jungle as a window into the complex dynamics of trauma.

Set in 1998 during the Second Congo War, The Mercy of the Jungle follows two soldiers, General Xavier (played by Marc Zinga) and Faustin (Stéphane Bak), as they attempt to rejoin their Rwandan regiment (which is responsible for hunting down fleeing genocide perpetrators) after having been inadvertently separated. Xavier, an experienced yet haunted solider, and Faustin, a new recruit eager to make a good impression, do not begin as friends. As they trek through the jungle, seeking refuge among the local Congolese population and fighting their way back to their home base in an odyssey-esque expedition, together Xavier and Faustin contend not only with the environment, but also with a complex sense of their own duty as soldiers and thus their complicity in this multidimensional conflict. While Mercy is a story of friendship and survival, it also deals with the difficult questions of guilt, revenge, and humanity as Xavier and Faustin increasingly question their role in and responsibility for the war around them.

As the third protagonist in the film, Mercy's jungle (referred to as such to highlight the equatorial forest's near-overwhelming density) is as complex and multifaceted as the soldiers who find themselves lost in its vast terrain. The environment has long figured into local and international imaginations of Africa-whether as part of colonial naturalizing 
of African peoples among their own landscape or as a site of revolution and resistance. Set in the liminal space of the borderlands, Karekezi's jungle oscillates between being a place of comfort and refuge and being a place of intense danger and vulnerability. This complexity is also shown in the secondary characters the soldiers encounter: a rapacious génocidaire commander, a local village elder, and an unfazed silverback gorilla (to name a few). Karekezi's cinematography highlights the jungle's beauty, particularly its lushness and richly saturated colors, while the sound track's focus on breath, wind, and sounds of the wilderness lends a peaceful yet eerie and isolating tone to the soldiers' journey into and through Congo's thick forests. The environment acts as a symbol for the conflict itselfintimate and familiar, while at the same time overwhelming and foreign. The jungle's centrality to the story recognizes the limitations of human agency and action and the entanglement between the human and the non-human.

The ecology of the jungle blends with multiple and layered ecologies of war and trauma. The jungle is at times a place of psychological mercy for Xavier, yet it also becomes a space of terror and death. In one scene of magical realism and traumatic hallucination, bloody ghosts of those he has killed confront the feverish General among the oppressively dense foliage. Xavier's feelings of guilt exist in stark contrast to Faustin's earnest insistence that he is a hero. While Faustin articulates a desire to avenge those he has lost, Xavier's inner turmoil illustrates the cost revenge can take on one's psyche and how morality becomes complicated in the slow violence of protracted warfare. Mercy challenges the oft-relied-upon war film binary of soldiers with guns as being either heroes or villains, protectors or perpetrators-in this film, they are simultaneously both and neither.

Karekezi's nuanced treatment of this history is furthered by his constant insistence on the sheer humanity of his protagonists. Captured in moments of kinship, humor, and playful interactions, joyful flashes of camaraderie remind the viewer that despite their traumatic pasts and trying present circumstances, Xavier and Faustin are also just two weary young men eager to return to their regiment (and in Faustin's case, to his pregnant wife back home). The often wry humor is perhaps unexpected in a film centered around war, trauma, and survival, yet these moments of lightness help to punctuate the seeming absurdity of the war itself without minimizing its very real consequences.

The Mercy of the Jungle is one of few feature films that deal with this recent history, and Karekezi skillfully handles this potentially difficult and politically charged material. Issues such as child soldiers, mineral extraction for funding local militias, civilian population displacements, and massacres are all featured, yet they do not override Karekezi's overarching message about the nature of shared trauma in the lingering disorder of war and survival. As it navigates the blurry borders between countries and conflicts, The Mercy of the Jungle offers an essential perspective that counters other, simplifying 
narratives of the region's history. In exploring the ecology of war through the lush borderland jungles of central Africa, Karekezi meaningfully argues that this history is anything but natural.

doi:10.1017/asr.2019.7

Alison MacAulay University of Toronto

Toronto, Canada

alisonc.macaulay@mail.utoronto.ca 